\title{
GPR68 wt Allele
}

National Cancer Institute

\section{Source}

National Cancer Institute. GPR68 wt Allele. NCI Thesaurus. Code C51460.

Human GPR68 wild-type allele is located within 14q31 and is approximately $20 \mathrm{~kb}$ in length. This allele, which encodes ovarian cancer G-protein coupled receptor 1 protein, plays a role in both G-protein coupled receptor signal transduction and in the stimulation of phosphoinositide hydrolysis. 